\title{
Changing Facets of Hyderabadi Tehzeeb: Are We Missing Anything?
}

Dr Vinita Pandey ${ }^{+}$

\section{Abstract}

In its historic evolution and development, the Hyderabad city has experienced many changes since its foundation as the capital of the medieval Kingdom of Golconda in the 16th century to its present status as the metropolis of a modern state. Each historic phase of development has significantly influenced its physical, social, economic and cultural growth. Hyderabad, under the influence of Deccan, Persian and indigenous culture, synthesised and evolved its very own Hyderabadi Tehzeeb. It truly represented the assimilation (yet uniqueness) of diverse cultures which inhabited Hyderabad. More than four hundred years later, HITEC city Hyderabad today presents a different picture. Whether it is its structural and spatial expansion, infrastructural development or its socio-cultural ethos, contemporary Hyderabad has evolved phenomenally and for many natives beyond recognition. Using ethnographic approach and secondary data, the paper introspects whether the City of Pearls has retained its unblotted tolerance and Hyderabadi Tehzeeb or has given up to the challenges of modern and globalizing times. Culturally, what is it that the natives of 'Bhagyanagar' irrespective of their caste, creed, gender, region and religion miss in modern Hyderabad.

Key words: Culture (Tehzeeb), Hyderabad, Ganga-Jamuna Tehzeeb (Hindu-Muslim culture), Social Changes and Cultural diversity, India

\footnotetext{
${ }^{+}$Department of Sociology, Nizam College, Osmania University, Hyderabad, Telangana, India Email: pandeyvini@gmail.com
} 


\section{Introduction}

Cities evolve with people of multiple cultures coming together. Cities are not only economic and administrative centres; they are cultural centres too. They present a unique picture of cultural accommodation and assimilation. The heterogeneity of city carries with it, its historicity, and amalgamation of several cultures of natives and settlers. Though all modern cities show similar cosmopolitan culture, the foundations of indigenous culture are so strong that its influence is felt in daily lives. All the culture influences collectively merge into the city mannerisms - Tehzeeb of the city. Tehzeeb (culture) does include ethos and eidos of culture. The key aim of this research is to understand the cultural changes owing to the impact of globalisation.

\section{History of Hyderabad}

The city of Hyderabad was founded by Muhammad Quli Qutub Shah, the fifth ruler of the kingdom of Golconda (see Figure 1); in 1591 A.D. on the south bank of the river Musi, that is a major tributary to the River Krishna. Hyderabad - Bhagyanagar - the city of luck symbolises spectrum of obsessions - love, pearls, cuisine, pan (betel leaves), Irani chai (tea), beautiful monsoons and many more. The icing, however, is the nawabi (luxurious and elite attitude) style and splendorous GangaJamuna Tehzeeb (co-existence of Hindu-Muslim Culture), the Hyderabadi culture is knitted through its history and, therefore, to understand the various facets of Hyderabadi Tehzeeb, it is worthwhile to walk down the memory lane of Qutub Shahis and Asaf Jahis, the dynasties, which not only laid down the foundation of modern Hyderabad but also critical to understand the history of Hyderabad.

A multitude of influences has shaped the character of Hyderabad. Its palaces and buildings, houses and tenements, gardens and streets have a history and an architectural individuality of their own, which makes Hyderabad a city of enchantment. For instance, Charminar (please see Figure 2) is of Islamic architecture with Persian elements of arches, domes and minarets. The history of Hyderabad can be broadly categorised under Qutub Shahi and Asaf Jahi period.

\section{Qutub Shahi Dynasty}

The history of Hyderabad begins with the establishment of the Qutub Shahi dynasty. Quli Qutub Shah seized the reins of power from the Bahamani kingdom in 1512 and established the fortress city of Golconda. Inadequacy of water and frequent epidemics of plague and cholera persuaded Mohammed Quli Qutub Shah to venture outward to establish new city. The new city had Charminar (which was constructed in 1591) at its centre and with four great roads fanning out four cardinal directions.

The Qutub Shahis ruled the Deccan for almost 171 years. All the seven rulers were patrons of learning and were great builders. Since Qutub Shahis patronised Persian culture, they contributed to the growth and development of Indo-Persian and Indo-Islamic literature and culture in Hyderabad. During the Qutub Shahi reign, Golconda became one of the leading markets in the world of diamonds, pearls, steel for arms, and printed fabric (Bhaunani, 1917). This brought people of different cultures together. The glory of the Golconda kingdom ended in 1687, after a valiant struggle. Aurangzeb, the last great Mughal ruler, captured Golconda after a siege that lasted for eight months.

\section{Asaf Jahi Dynasty}

After the Moghul ruler Aurangzeb's seizure, the importance of Hyderabad declined and the city fell into partial ruins. As the Moghul Empire decayed and began to disintegrate, the viceroy, Asaf Jah I proclaimed himself as the Nizam and established independent rule of the Deccan. Hyderabad once again became a major capital city, ruled by successive Nizams of the Asaf Jahi dynasty until the state was merged into Indian Union in 1948. The seven Nizam's of the Asif Jahi dynasty ruled the Deccan for nearly 224 years, right up to 1948 (Alikhan, 1991). 


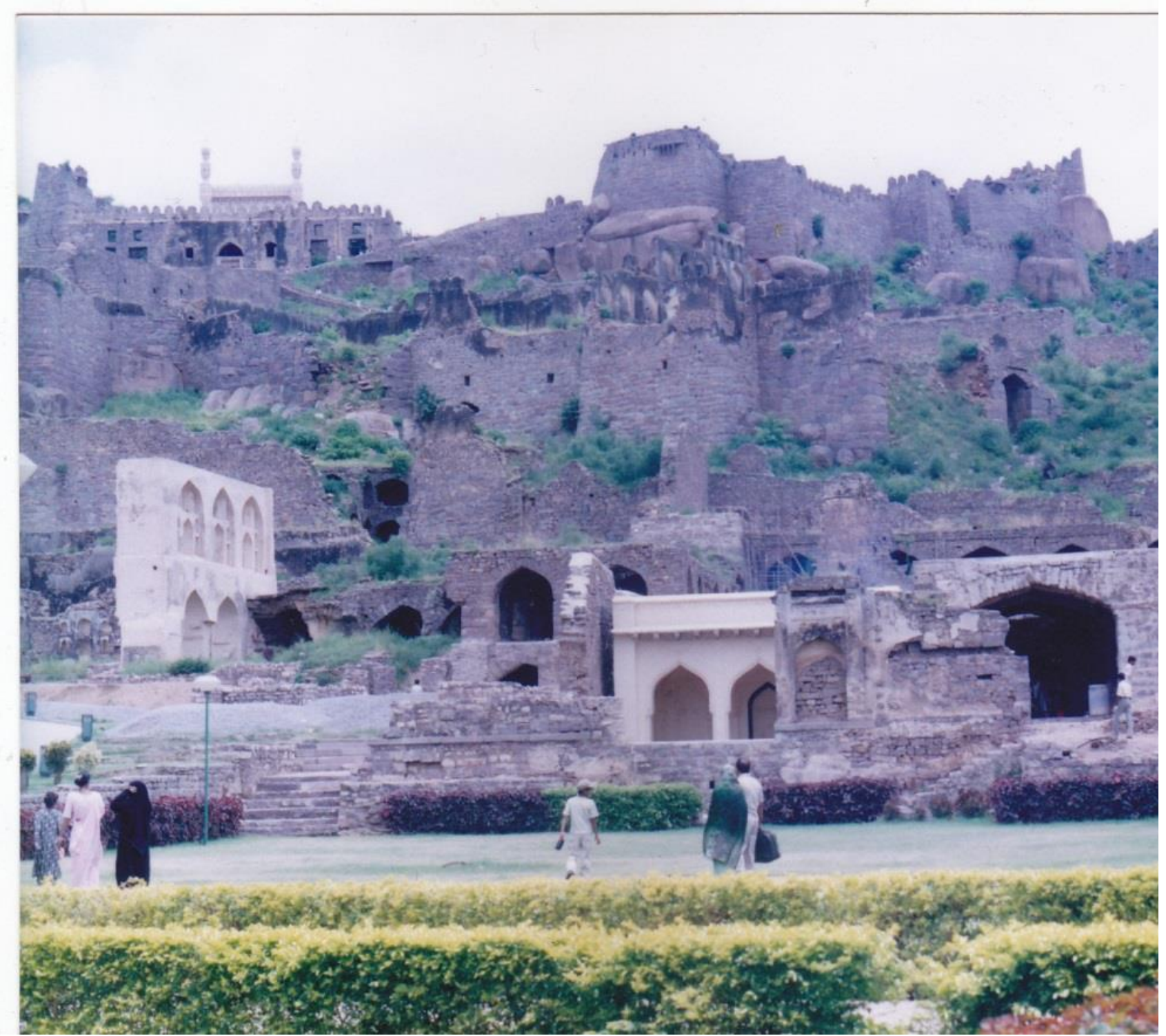

Figure 1: Golconda Fort - Reflections of Glorious history Picture Courtesy: Mr. Santosh Kumar Pandey 


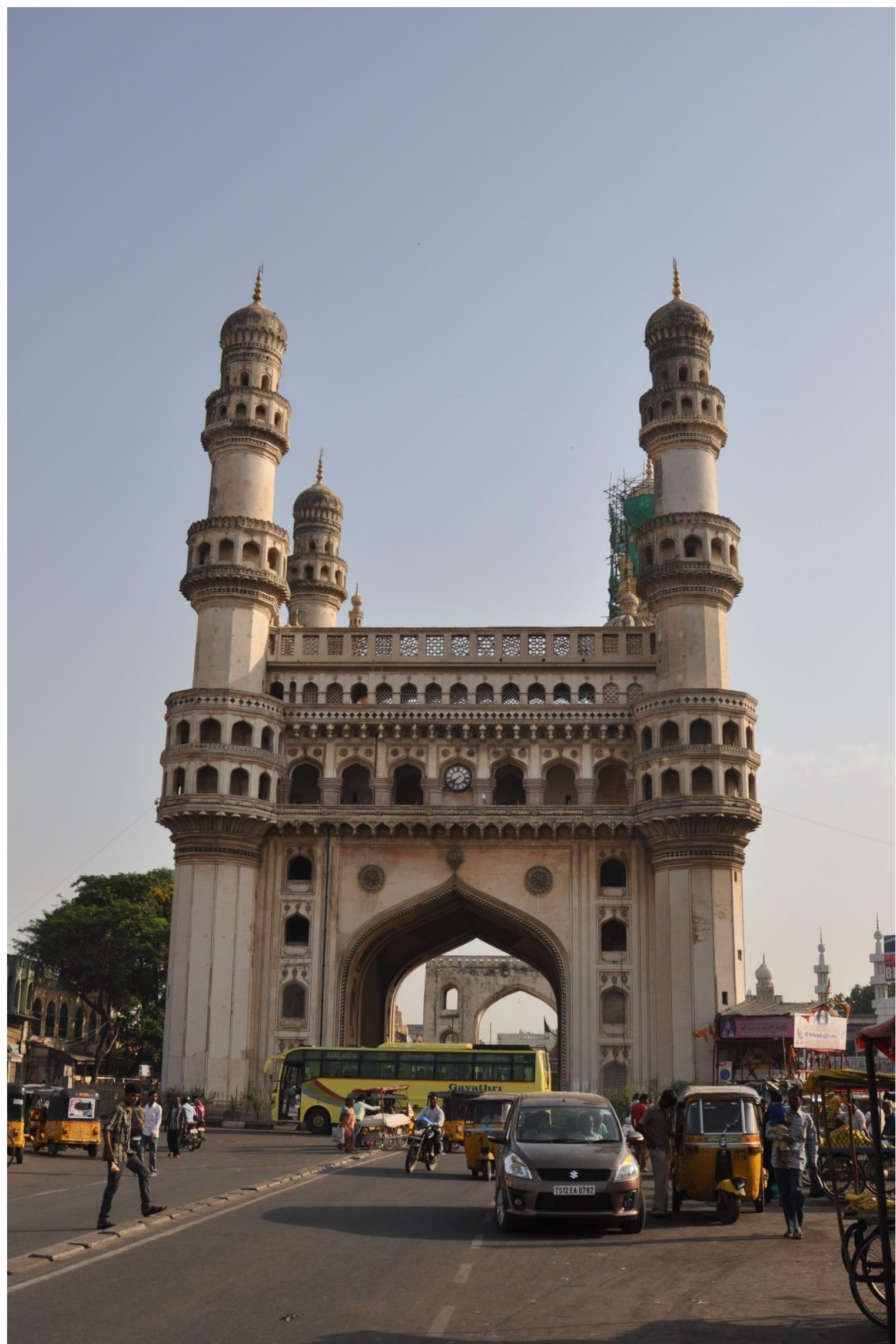

Figure 2 Charminar - Symbolic of Hyderabad and an Architectural Marvel Picture Courtesy: Mr. Santosh Kumar Pandey 
During the Asaf Jahi period, Persian and other languages especially spoken in the Deccan region of India - Urdu, Telugu and Marathi developed simultaneously. The highest official positions were given to deserving persons irrespective of their religion. Persian was the official language, and it remained until 1893, taken over by Urdu until 1948. When the British and the French spread their hold over the country, the Nizam soon won their friendship without bequeathing his power. The title "Faithful Ally of the British Government" was bestowed on Nizam VII. The British stationed a resident at Hyderabad, but the state continued to be ruled by the Nizam.

Hyderabad's twin city Secunderabad shares a similar history even if it is quite different culturally in contemporary times. In 1798, a subsidiary alliance for military and political cooperation was signed between the Nizam and the British East India Company. Thereafter, an area north of what is now the Hussain Sagar was established as a British cantonment. The area was named Secunderabad after the then Nizam, Sikander Jah. The essential difference between Hyderabad and Secunderabad is that the former was a feudal Muslim city, while the latter was a cosmopolitan colonial town initially. However, Secunderabad has evolved into a cosmopolitan twin city of Hyderabad. Hyderabad was where the Nizam lived; Secunderabad housed the British resident who wielded the real power in the state. The Nizam's prime ministers were selected or approved of by the resident before the ruler formally appointed them. Every prime minister first called on the resident who returned the call.

The Nizams were popular for their riches and wealth. Speaking about the seventh Nizam Luther reflects, "[t]he seventh - and the last ruling - Nizam, Mir Osman Ali Khan, was reputed to be the world's richest man of his time. He had no idea of his wealth, not surprising for a man whose personal estate yielded 2.5 million rupees and whose privy purse was five million rupees a year. Besides, in 1919 , he published and became the sole selling agent for the six collections of his poems for one guinea each. The guinea is a coin of approximately one-quarter ounce of gold that was minted in the Kingdom of England and later in the Kingdom of Great Britain and the United Kingdom between 1663 and 1814. (Yes, the price was fixed in guineas! It was equivalent to twenty-one rupees). He was also presented a nazar whenever a visitor was given the privilege of an audience. The minimum amount for a nazar was one gold and twenty silver coins twenty-four rupees!" (Luther, 2008).

The Nizam's rule saw the growth of Hyderabad economically and culturally. Electricity, railways, roads and airways developed. Huge reservoirs and irrigation projects such as the Tungabhadra, and Nizam Sagar were completed. The early work on Nagarjuna Sagar was undertaken. The Osmania University and several schools and colleges were founded throughout the state. Nearly all the public buildings such as the Osmania General Hospital, High Court, Central State Library, Assembly Hall, Jubilee Hall and other buildings in the Public Garden were built during the reign of Osman Ali Khan. Soon after India gained independence in 1947, all the princely states were invited to join the Republic. Nizam VII was reluctant to do so; but in 1948, after the Police Action (Operation Polo), his state was merged into the Indian Union. Operation Polo refers to the Indian military operation, which resulted in the integration of the State of Hyderabad and Berar into the Union of India on September 12, 1948. This Operation is often popularly referred to as a Police Action. This was the first large-scale military operation carried out by independent India. Mir Osman Ali Khan, the last Nizam, died on Friday 24 February 1967. It was the end of the princely era.

At the time of India's independence, Hyderabad was the largest Indian princely state in terms of population and GNP. ${ }^{1}$ The State had its own currency, mint, railways, and postal system. There was no income tax. Its territory of 82,698

\footnotetext{
${ }^{1}$ GNP is the market value of all the products and services produced in one year by labour and property supplied by the citizens of a country.
} 
sq. miles (or $51355.458 \mathrm{sq}$. kms) was more than that of England and Scotland put together.

\section{Post-1947 Hyderabad}

The years 1947 to 1956 were very crucial in the history of Andhra Pradesh. When India gained independence on 15 August 1947, the three main regions of Andhra Pradesh - Coastal Andhra, Rayalaseema and Telangana were not part of Andhra Pradesh state.

Telugu-speaking people demanded for their long-cherished Visalandhra formation, but people of Hyderabad state were unanimous in their demand for splitting the state into three parts. The States Reorganization Commission headed by Syed Fazal Ali heard the views of different people and organisations. The state of 'Andhra Pradesh' emerged merging all the districts of Coastal Andhra, Rayalaseema and Telangana on November 1, 1956. However, on 2nd June 2014, the state of Andhra Pradesh was bifurcated and new state of Telangana with Hyderabad as its capital has been formed (Guenther, 2014).

\section{Culture of Hyderabad - Hyderabadi Tehzeeb}

The culture of Hyderabad - the Hyderabadi Tehzeeb is the result of evolution and assimilation of several cultures some of which were transitory (like British and French) and some cultures which made Hyderabad their home and thereby assimilated with other cultures. The arrival of different cultures though dates back to the period much before Qutub Shahis. The present Hyderabadi Tehzeeb foundations were laid during the Qutub Shahi time. Different communities from north and south India migrated to Hyderabad during different times of the reigns of Qutub Shahi and Asaf Jahi. Subsequently Hyderabad became the meeting ground of practically all the elements of the population of the country. Many families from north India came in the early 10th century. These communities played a significant role in the political, social and cultural life of Hyderabad.

It has been articulated that the impact of Persians on the culture of Hyderabad. That is, Persians were a part of the cultural make-up of
Hyderabad ever since the founding of the city in 1591 A.D. This was natural because the nobility held the ruling dynasty of the Qutub Shahis, who came from Persia, which is the presentday Iran, and the most important positions in the administration of the Kingdom from Iran. This factor had a tremendous impact on the art, architecture, literature and culture of Hyderabad for nearly two hundred years after its foundation, and the influence is clearly visible in all these areas. There was hardly any facet of life in Hyderabad, which did not bear the mark of Persian influence. There may have been a decline in the Iranian influence, but it never wholly disappeared and individuals and families of Persian origin continued to wield a great deal of influence until very recently and continued to shape the way of life at least among the higher classes in Hyderabad (Prasad, 1986).

While analysing the cultural heterogeneity of Hyderabad, Sheela Raj says that Hyderabad's heterogeneous society included both Muslims and Hindus, and men of diverse ethnic, racial, religious and social backgrounds. Hyderabad was full of diverse groups belonging to different castes and classes. Hence, the people of Hyderabad were influenced by multiple cultures (Raj, 1987). It is this influence which has shaped the Hyderabadi Tehzeeb.

Through the centuries, the ethnic Telugus of the region have intermingled and amalgamated with the people who have come over and been made welcome to this region of the Deccan. The fusion has brought about a special composite Hyderabadi culture that has evolved between its Telugu population and the Mughals from the North of India with whom Hindus of the Kayasth community came in the 16th century, and occupied important posts in the state. Kayastha (also referred to as Kayasth or Kayeth) is a caste or community of Hindus originating in India. Kayasthas are considered to be members of the literate scribe caste, and have traditionally acted as keepers of records and public accounts, writers, and administrators of the state. There was a further influx of Turkish and Persian scholars, artists, 
craftsmen and traders who came between the 16 th and 19th centuries, invited by the rulers to embellish the forts, tombs and other structures. This interaction and mingling amongst those of different regions and lands also led to the emergence of a beautiful language, Urdu, with its colourful locally spoken Hyderabadi Urdu or 'Dakhni Boli' (Deccan dialects) which often includes an element of humour at one's own expense (Latif, 2008).

The composite culture is reflected in varied dressing patterns, food habits, customs and traditions. In medieval Hyderabad, Hyderabadi Tehzeeb was greatly reflected in simplicity. People were very simple and mostly stuck to their religions but they paid due respect to each other's religion. Sheela Raj writes that this simplicity of the culture was also reflected in the people's attires. Generally speaking, the ordinary forms of the dress in the rural areas of Hyderabad was dhoti or waist cloth, a short jacket or coat of cotton, a red or white turban in the Marathwada region, and always white in Telangana. They carried Kambal or blanket irrespective of whether (Hyderabad, however, had moderate weather with most of the houses without fans). Both Hindus and Muslims wore this. Hindu women used to wear saris and cholis (blouses) but Muslim women often wore a lehanga or petticoat, with a choli (blouses) and dupatta (long scarfs or stoles that is essentially part of South Asian women attire). The dastar or the headdress of the people of Hyderabad was of different types. Different types of family or traditional dastars used by the people was the identification of their profession, caste and family. Wearing of another's dastar was considered uncultured. Those whose fathers were dead wore white dastars and others used colors according to their whims. Of the entire dress, dastar was supposed to be symbol of respect (Raj, 1987).

Among Telugu community, Langa Odhni (half sari) was a very prominent attire of young women and girls. The plaited hair decorated with jasmine flowers projected a beautiful picture of Hyderabadi Tehzeeb. However, the onset of globalisation has brought new attires which are relatively modern Although globalization is often mistaken as an exclusively economic phenomenon, it is obvious that "humans on all frontiers are being forced either to shift their ideational systems radically and quickly or to live in a thought-world that no longer fits the way their world is" (Keesing \& Keesing, 1971: 343). Keesing points out that as "rewards of "economic development" become universal aspirations; they [people] react to this challenge in sharply contrasting ways". From this perspective, globalization cannot continue to be exclusively defined as an economic development, but it has social, cultural and political effects must also be addressed.

The traditional Muslim family in Hyderabad had a separate Zenana (pertaining to women). Zenana or the interior part of a house particularly meant for the women was separate place in a common Muslim household (Chakrabarty, 2014). Privacy was secured by means of thick-wadded curtains, which are called parda, generally made of coarse cloth according to individual taste. Parda was strictly observed among the Muslims, and few Hindu families (Chakrabarty, 2014; Sur, 2014). Besides parda, the openings between the pillars had blinds made of bamboo strips, woven together with coloured cords. These were called chilman. Many of them were painted green since green is a very soothing colour to eyes.

The Hyderabadi Tehzeeb has its own charm and attraction. Narendra Luther says "[i]n 1591, the fifth Qutub Shahi Sultan of Golconda, Mohammad Quli built a city as 'a replica of heaven'. He named it Bhagyanagar, after his beloved Bhagmati. In 1983, the German architect Jan Pieper quoted chapter and verse to argue that the city was indeed an architectural metaphor for the Quranic heaven" (Luther, 2008).

Great temples for pilgrimage, famous diamond mines, and international trade attracted people from many regions. There was contact with distant lands through coastal trade that included the export of precious stones, and printed textiles, especially of the famous chintz 
that was so popular with the ladies of Rome and further into Europe. Bilkees Latif writes that the beautiful dakhni style of miniature painting, the famous kalamkari hand-painted textiles depicting the Persian tree of life as well as scenes from our Ramayana is equally a legacy of Hyderabad's cultural fusion (Latif, 2008).

The romanticism of Hyderabad is so much inherent in Hyderabadi Tehzeeb. There is something romantic in the air of Hyderabad, which has been highlighted by Bilkees Latif and Narendra Luther. Narendra Luther, while comparing Hyderabad and Taj Mahal, says Hyderabad is to cities what Taj Mahal is to buildings - a monument to love. Both were named to commemorate the respective beloveds - Taj for Mumtaz, Bhagyanagar for Bhagmati. While Taj symbolised a pining for a departed beloved soul, Bhagyanagar was a celebration of a union of lovers. Taj was to enshrine a resting place for a departed queen, Bhagyanagar to provide living space for her subjects (Luther, 2008).

The Hyderabadi Tehzeeb is Ganga-Jamuna Tehzeeb, which shows glaring example of synthesising Hindu Muslim culture and obviously, which had its roots in the history of Hyderabad.

Highlighting the diversity of the ruling elite, Narendra Luther writes that Aurangzeb's hated jaziya - poll tax - was never imposed in the South. On the other hand, a broad streak of secularism runs through its history. In 1805, a Kayasth noble, Raja Bhavani Pershad, built the first Kayasth temple at Rambagh near Attapur. The third Nizam, Sikander Jah, performed the installation ceremony of the idols of Rama, Sita and Lakshmana. He also granted a jagir ${ }^{2}$ of ₹12000 for its maintenance. The population of the state of Hyderabad was predominantly Hindu. Its founding dynasty, Qutub Shahi, subscribed to the Shia sect of Islam. The Asaf

\footnotetext{
${ }^{2}$ A Jagir, also spelled as Jageer (ja- meaning "place", -gir meaning "keeping, holding") was a type of feudal land grant in South Asia bestowed by a monarch to a feudal superior in recognition of his administrative and/or military service.
}

Jahis were Sunni. ${ }^{3}$ Of the ten highest noble families under them, one was Sunni, five Shia and four Hindu. Out of the Hindu families, two were Deccani, and two from North India - one Kayasth and the other Punjabi Khatri, tracing their ancestry to Todar Mal, Akbar's celebrated revenue minister. This diversity of the ruling elite imparted a distinctive flavour to the Hyderabadi culture (Luther 2008).

Apart from multiple indigenous and Asian cultures, which imparted distinct flavour to Hyderabadi Tehzeeb, European culture set the direction for the modern day Hyderabad.

Both British as well as French have equal importance in setting up many institutions that became the root of solid Western education system in Hyderabad, since 17th century itself. This also helped in expanding the city with Western culture in northern side of the River Musi. The Nizam, during various times, had both French and British as part of his army, but maintained in separate locations outside his main city. Only the Nizam provided the money required for maintaining the army.

During Asaf Jahis (Nizams), it was glorious period of architecture, under whose reign Hyderabad's Twin City, Secunderabad was founded. The Osmania University, the Chowmahallah Palace, the King Kothi Palace, the Falaknuma Palace are few examples of grand architecture during the Nizam age. During the same era, Secunderabad was built as a station for the French and later British troops. The Army barracks, clubs and homes in Secunderabad exhibit tremendous inspiration in architecture style from English. The highly adaptive city took the newness of dotcom boom (the IT revolution) in its stride when a part of the city was rechristened Cyberabad and Hitec City (please see a glimpse of Cyber

\footnotetext{
${ }^{3}$ Muslims who wanted to select his successor, or Caliph, by following the traditional Arab custom (Sunna) formed into a group known as Sunnis. Others insisted the Prophet had designated his cousin and son-in-law Ali as his legitimate heir. This group was called Shia Ali, or 'Party of Ali', from which comes the word Shia. (http://www.bbc.co.uk/)
} 
Towers, Figure 3). In 21st century, Hyderabad, the jewel in the crown is the Rajiv Gandhi International Airport. Further several structures in Gachibowli, including IT companies and convention centres like HITEX, are magnificent examples of modern-day infrastructure.

\section{Hyderabadi Food - The Dastarkhan Tehzeeb}

Food is imminent part of any culture. Hyderabad is known for its world popular Haleem and Biryani. Hyderabadis love to eat. Bilkees Latif writes that most conversations seem to end with a discussion on food! In restaurants all over town or even if one is walking down a street at dusk, one gets the aroma of saffron and cardamom from a hot kachi biryani of fine rice and succulent meat, of which it is said that once eaten it will draw you back to the city for more! Hyderabad food has its own character depicting its composite culture. The food has the flavours of saffron, cardamom and nutmeg from Persia, the rich fried spices in ghee from northern India, enhanced by its basic, piquant, local Andhra ingredients of sour tamarind fruit, curry leaves and hot red chillies in meat, seafood, fowl or crisply fried vegetables and spicy, chilli hot dishes. Chilli hot food is followed with a helping of plain yoghurt and boiled rice to cool down the fiery fumes, and the rich spices (masalas) in the baghare baingan (spicy brinjal curry with gravy) and mirchi ka salan (green chilli curry with spicy gravy) become easy to digest because of the addition of tamarind, so popular in Telangana (Latif 2008).

All meals were served on the floor where dastarkhan (white cloth spread over carpet for traditional meal) were spread, but knives, forks, spoons, glasses or napkins, considered essential to the enjoyment of a meal by the Europeans, were never used. Dastarkhan of both Hindus and Muslims had great importance, with a variety of food in the day-to-day life of the people of the Hyderabad. It was part of the social life of the people, who were known for their hospitality. This was a mark of the magnificent Deccani culture. Whether poor or rich, all were equal in showing hospitality.

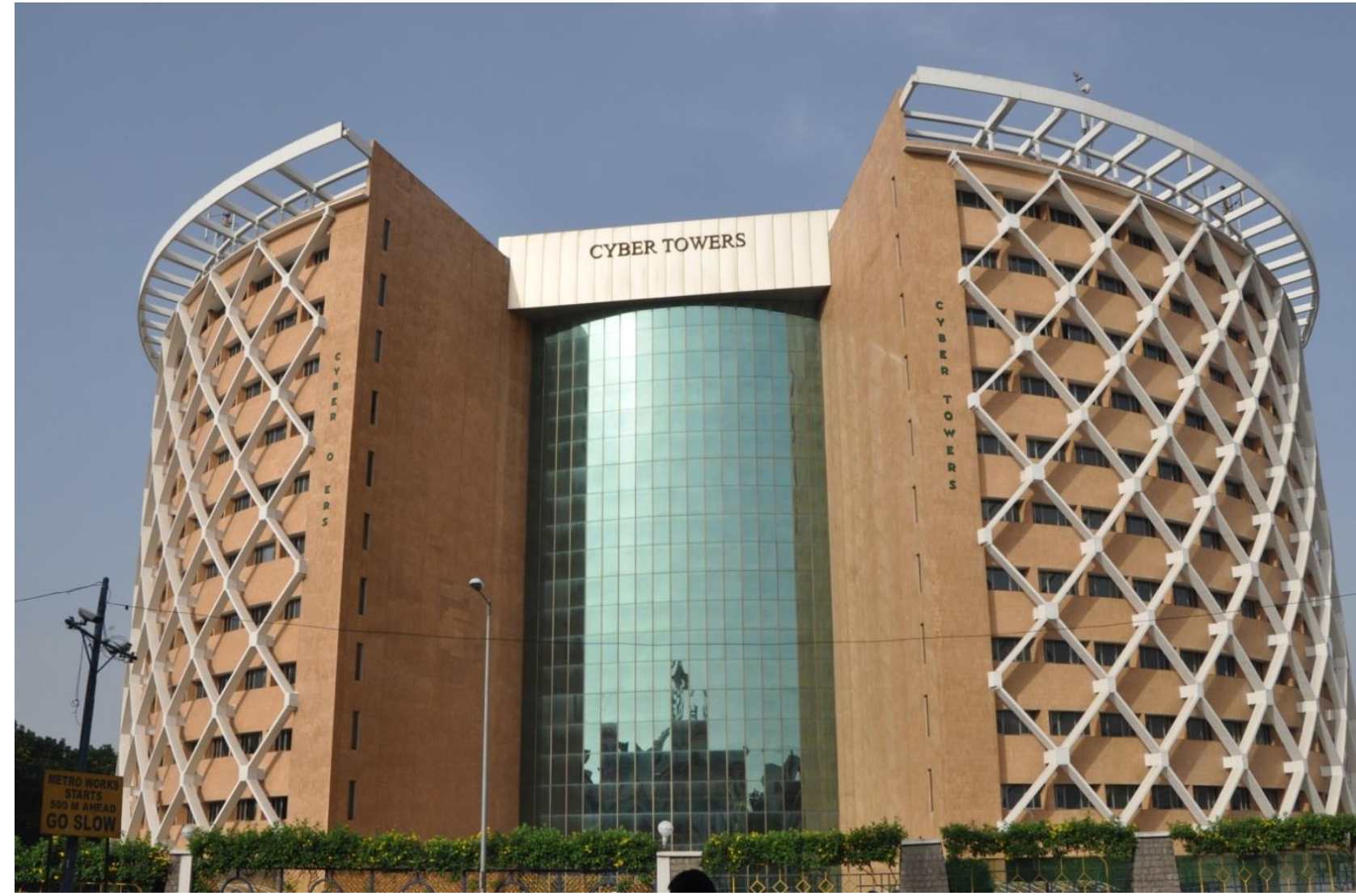

Figure 3: Cyber Towers - Symbolising Cyberabad - The IT Hub Picture Courtesy: Mr. Santosh Kumar Pandey 
This was a mark of the magnificent Deccani culture. Whether poor or rich, all were equal in showing hospitality. Cooking in Hyderabad was an art in itself in former times and to some extent, even today. The neat and clean dastarkhan decorated with skilled techniques like embroidery and lace work were marks of the host's good taste.

Traditionally, the people of Hyderabad ate rice and sour things in plenty without caste and class distinction. A proportionate quantity is put in specific food, which improves its taste and is said to be good for health. Shahid Sidiqui (quoted in Raj, 1987, in this article 'Hyderabad ki Biryani' wrote "[i]f sherwani is our national dress, then biryani is our national dish". (Here the word 'national' is used in a limited sense). Parties either in connection with the marriage or in connection with circumcision even today are supposed to be incomplete without Biryani. Different types of vegetables were cooked (and are cooked) either separately or with mutton. As discussed above, Baghare baigan and Mirchi $k a$ salan is a peculiar dish of Hyderabad. It could be kept for a number of days. Similarly, kut prepared with tomatoes and kulti was the oldest and most popular Hyderabadi dishes (Raj, 1987.

All these dishes are even today widely consumed in the region. European dishes like bread, biscuit, cake, pastry, pudding, ice cream, fruit salad were introduced during the late nineteenth century. The Nizam had a department known as amra, which arranged state dinners, lunches and at-homes by experts of the department. For example, Berganaza from Goa was a specialist in European food. With the advent of Europeans in Hyderabad, different types of drinks were introduced. With "cyber culture" developing in Hyderabad, contemporary Hyderabadi food includes all types of food, including inter-continental food (Italian, Mexican, Mediterranean, etc.).

Hyderabadi's Irani chai is so much part of its Tehzeeb. The Irani cafes best delight is Irani chai, Osmania biscuits and Irani samosa. Among other beverages, south Indian coffee, bandi chai addiction is common among Hyderabadis. The modern Hyderabad is witnessing bandi food culture and curry point culture. Morning breakfast (Idly, Wada, Dosa, etc.) and evening snacks on bandi (mobile stalls) are increasingly common.

The description of Hyderabadi Tehzeeb is incomplete without mentioning the typical Hyderabadi argot. It is so much part of Hyderabad's culture. Karthik Pasupulate, in his article Hum aiseich hai, mentions about interesting words and phrases of Hyderabadi lingo - Jump Jilani (runners who ran to save their lives), de thadi pochamma gudi (not backing down, what may come), hand ichadu (pure Telugu slang for when someone ditches you), bada hath de diya yaron; kya baingan ke baata karre ji, khamush baitho (Pasupulate, 2012). This can be attributed to assimilation of many languages and dialects.

Elaborating on usage of word purson (pronounced as per soon) in Hyderabad, Narendra Luther says "[o]ld people used to tell me that the worst floods in the city occurred purson - the 'day before yesterday'. They meant 1908. In the Hyderabadi lexicon, the term covers "all remembered past" (Luther, 2008).

The famous Laad bazaar is so much sought for pearls and bangles especially the lac bangles, which is a vital identity of Hyderabad.

\section{Social Changes and the Missing Element}

In its historic development, the Hyderabad city has experienced many changes since its foundation as the capital of the medieval Kingdom of Golconda in the 16th century to its present status as the metropolis and megacity of a modern state. Each historic phase of development has markedly influenced its physical and cultural growth, while the Golconda period was known for the promotion of Shiite Iranian cultural, it encouraged equally the development of the native Telugu culture in the city which is indicated by the fact that the rulers themselves were conversant with the 
Telugu language and some of them even composed poetry in this language.

In more than four centuries of its existence, Hyderabad has seen innumerable socio-cultural changes. In past two decades, its expansion has been phenomenal so much so that it reflects multiple identities even if it subsumes in identity of Hyderabad. Christina Francis says that the "Twins" (twin cities of Hyderabad and Secunderabad) have grown so much that they have developed four very distinct identities over the years. Distinct enough to seem like four mini cities - Old City, New City, Tech City and Secunderabad - masquerading as one colourful Hyderabad. Hyderabad acquires a new identity and Hyderabadi flaunts a new personality, every 25 odd kilometres. With the IT industry and corporate culture becoming a parallel lifeline, a Tech city (Madhapur, Kondapur, and Gachibowli) has formed for new age Hyderabadi who has chosen to stay in the city for the opportunities it provides (Francis, 2012).

Anyone who is born and brought up in Hyderabad and has seen its evolution in the past 2-3 decades shall definitely vouch that there is some element of our culture, our Hyderabadi Tehzeeb which is missing, though it is difficult to identify the exact missing element. The social and secular tolerance, which defined Hyderabadi Tehzeeb, seems to be diluted even though many residents still retain the secular spirit.

Narendra Luther, very precisely and emotionally, brings about the change in Hyderabad and the missing element. He says that Hyderabad was conceived in the image of heaven. All its gardens and low buildings have been gobbled up by new apartment buildings. Multi-storey malls have sprung up even in the exclusive residential areas. Its arteries are choked, its breath polluted, its heritage all but vanished. The 2.5 billion-year old, fascinating rocks are being recklessly destroyed. Paradoxically, while people's income is going up, their quality of life is plummeting. Nostalgia is for that lost heaven of broad concrete roads, of a low skyline, and of gardens. It is a longing for a world of laid-back life, of courtesies, of mushairas, qawwalis and chowki dinners. It is a yearning for the sepia tones of yesteryear. I too suffer from nostalgia. I came to this city five decades ago. I still live in Hyderabad, but where is Hyderabad, O bird of time? (Luther, 2008).

Secularism is the very fabric of Hyderabadi Tehzeeb. Though we have been living and projecting the secular spirit, it is sad to see that religious festivals have become means to reflect strength and power. The warmth of the people and relaxed attitude is missing. Vanaja Banagiri says that gone are the days of nawabi attitudes and laid-back lifestyles. Everything is on a fast track. From economic development to attitudinal change, Hyderabad has undergone a tremendous metamorphosis. Steering the growth are the city's young. With their restlessness to be a part of the hip and happening, and energy levels to match, they have redefined all things hitherto known as Hyderabadi (Banagiri, 2008).

The apartment culture has become a necessity keeping in view the space crunch. It has been debated that apartment culture is discouraging the people of diversified religion and castes staying together. Until recently, that is a decade ago, Hyderabadis could not relate to the apartment culture. After much resistance, they have succumbed to the housing demand and escalating land rates, and one finds high rises mushrooming in and around the city. Fortunately, some areas like Jubilee Hills are protected from the onslaught of modern-day wonders and still retain the charm of homes with gardens.

The societies undergo change. In fact, change is the permanent feature of society. The forces of modernisation have become predominant owing to globalisation. There is not only exchange of goods and services but also cultural diffusion taking place at a very fast pace. In past one decade, the topography of Hyderabad has witnessed sea change with IT companies and malls becoming an imminent part of the culture. The mall culture has popularised its own distinct lifestyle. Jyotirmayi Sharma while writing about the change in 
Hyderabad says “...[t]hey don't drink water from the Gandipet Lake and, mercifully, will go away in a few years. They live in gated communities, sit in soulless offices, hardly ever mingle with the local community, retire on weekends to the antiseptic but noisy confines of pubs, and return to their pigeonholed existence on Monday morning. They ignore the city and the city ignores them" (Sharma, 2008). Osman Sagar was created by damming the River Musi in 1920, to provide an additional source of drinking water for Hyderabad and to protect the city after the Great Musi Flood of 1908. It was constructed during the reign of the last Nizam of Hyderabad, Osman Ali Khan, hence its name.

A princely guesthouse called Sagar Mahal, overlooking the lake and now a heritage building, was built as a summer resort of the last Nizam. Its location on the banks of the lake offers wonderful views. The breeze of the lake is very pleasant and has been popular with the locals since the Nizam's time.

The expansion of the city has led to increased travel time. The social interactions between people have assumed new dimensions with weekend parties and pub culture making its strong presence feel.

Many passionate Hyderabadis at various platforms have asserted it, in several write-ups, monographs and ethnographies that Hyderabadi Tehzeeb evokes images of charm and romance, grandeur and splendor woven with legend, which over the years has continued to inspire contemporary folklore. Popular renditions of the city, much like those of its counterpart city in the North, Lucknow, reminisce about the syncretistic Hindu-Muslim culture, a Ganga-Jamuna Tehzeeb, and an elite drawn across denominational divides that left behind not just iconic wonders like the Charminar, the Chowmahalla and the equally marvelous palaces and baradaris (Baradari also Bara Dari is a building or pavilion with 12 doors designed to allow free flow of air. The structure has three doorways on every side of the square shaped structure) but a fusion cuisine marked for its distinction and the attractive speech,
Deccani Urdu (Hyderabadi Urdu is a dialect of Urdu spoken in areas of erstwhile Nizam's Hyderabad State (now in Telangana, Marathwada region of Maharashtra and Hyderabad-Karnataka region of Karnataka) and its diaspora. It is also known as Deccani Urdu from its former name Hyderabad Deccan. It contains loan words from Indian languages like Marathi, Telugu, Kannada and foreign languages like Arabic, Turkish and Persian).

All these descriptions are true but somewhere undermining the present reality. Beyond the glories of the Nizami era, buildings, pearls and the enjoyable cuisine, the contemporary Hyderabad has expanded, and so are its challenges and predicaments, which bring forth the clashes between castes, class, religion and regions. The usual najaakat, mannerisms and courtesies, which were part of everyday social interactions between common people, seem to be missing. The best example is the way autowallahs (auto drivers) rough up the commuters. The relaxed pace of the city has transformed drastically. The attires have changed. Western and modern wears have replaced traditional attires. The concrete jungles and pollution have taken away the brightness from the stars and has dimmed the pole star.

Not only is contemporary Hyderabad, an eight million plus agglomeration, more and different from the erstwhile capital of the Asaf Jah dynasty, we need to revisit its history to grasp both the energy and tensions marking the populace and its popular culture. Equally, without understanding the relations between the city and its hinterland, more extractive than synergistic, we may miss out on its future.

The city, in its frenzied pace, is choking its resources especially land and water. The city, which was known as 'City of Lakes' is witnessing destruction of local water bodies and phenomenal change in land use pattern.

In fact, cities change; but change should not snatch the identity and the Tehzeeb, which defines the identity. For a visitor, Hyderabad may present a very satisfactory picture but for those residents who see Hyderabad changing at 
such high pace, the change is not always welcome. In fact, in the winds of these changes the basic nuances of Hyderabadi Tehzeeb is gradually missing.

Nevertheless, despite the missing element, the Hyderabadis love and adore the city but do sigh for the missing element. Just to conclude and quote the content in a seminar write up (City of Hope - a symposium on Hyderabad and its syncretic culture, May 2008) “...[w] hat shape this will take remains uncertain, but the city still retains its soul and generates fierce pride among its resident mulkis and migrants. Even if somewhat frayed, in part more myth and memory than fact, there is no gainsay the languorous grace and welcoming spirit, just what makes Hyderabad so special."

\section{Acknowledgements}

My deepest appreciations and gratitude to 1) Dr Venkat Pulla, Social work Discipline Coordinator, Brisbane, Australian Catholic University and member of the editorial boardSpace and Culture, India; 2) Dr Kanchana Thambidoriai, Anthropologist, Bonn, Germany; and 3) All internal reviewers for their very constructive inputs

\section{References}

Alikhan, Raza (1991). Hyderabad: 400 Years (1591-1991), Australia: Allen and Unwin. (ISBN$10-1117445941)$

Bhaunani, A.P.A. (January 1917). A Short History and the Foundation and Growth of the City of Hyderabad and Some of its Buildings. The Hyderabad Archeological Society

Banagiri Vanaja (2007). Butterflies and Barbed Wires, Delhi: Rupa (ISBN-13: 978-81-291-08821)

Chakrabarty, Priyanka (2014). A Contemplation on 'Sultana's Dream', Journal Space and Culture, India, 2(1): 33-39

Francis, Christina (2012, September 22). Twin Cities Four Identities: Hyderabad, Times of India, available at:
http://timesofindia.Hyderabad Times/ (accessed November 21, 2014)

Guenther, Julia (2014). Feminist Collective Activism in Telangana, South India: Exemplary by the Andhra Pradesh Mahila Samatha Society, Journal Space and Culture, India, 2 (2): 17-27

Keesing, R.M. and F.M. Keesing, (1971). New Perspectives in Cultural Anthropology, New York: Holt, Rineheart and Winston, Inc.

Latif, Bilkis (2008). The Soul of Hyderabad, available at http://www.india-seminar.com (accessed October 8, 2014)

Luther, Narendra (2008). Bridging Two Cultures, available at http://www.india-seminar.com (accessed October 8, 2014)

Moorthy Neeraja (2015 April 17). Story of Changing Hyderabad, The Hindu, available at http://www.thehindu.com/features/metroplus /story-of-changing-

hyderabad/article7113177.ece. (accessed April 27, 2015)

Pasupulate, Karthik (2012 September 22). Hum Aiseich Hai: Hyderabad, Times of India, available at: http://timesofindia.Hyderabad Times/ (accessed November 21, 2014)

Prasad, Dharmendra (1986). Social and Cultural Geography of Hyderabad City: A Historical Perspective, New Delhi: Inter Alia Publications (ISBN - 81-210-0045-9)

Raj, Sheela (1987). Medievalism to Modernism: Socio-Economic and Cultural History of Hyderabad - 1869-1911, Bombay: Popular Prakashan (ISBN - 86132-143 X)

Sharma, Jyotirmayi (2008). Shahar Baaki Hai Mohabbat Ke Nishaan Baki Hai, available at http://www.india-seminar.com (accessed October 8, 2014)

Sur, Esita (2014). Revisiting the Marginal Locations of Muslim Women on Various Sites in India, Journal Space and Culture, India, 1(3): 4352 